\title{
Factors Limiting Female Access to Science Related Programmes in Technical Training Institutions in Nyanza Region, Kenya
}

\author{
Mr. George Ochieng Ohanya \\ Siaya Central Primary School, Box 24, Siaya \\ ohanya@yahoo.com \\ Dr. Jack Odongo Ajowi*
}

Jaramogi Oginga Odinga University of Science and Technology, Box $210-40601$. Bondo

jackajowi@yahoo.com

Doi:10.5901/ajis.2015.v4n1p355

\section{Abstract}

The low enrolment of female students in science related courses in tertiary institutions in Kenya has been in the public domain for some time and it is of concern to education policy makers. Women's equal enrolment with their male counterparts in science related courses is key to drive Kenya's Vision 2030. This initiative aimed at making the country a newly industrializing middle income country by providing high quality life for all its citizens. The purpose of the study therefore was to determine factors which influence female access to science related programs in technical training institutions in Nyanza Region, Kenya. The specific objectives of the study were to: determine the enrolment failures of female compared to male in science related courses; assess factors which influence female access to science related programs and determine factors that can promote female access to science related programs. The related literature reviewed has revealed that there is low enrolment of female students in public technical training institutions in Nyanza Region. The conceptual framework adapted to guide the study showed that there are several conditions which need to be put in place to enable female enrolment in science related programs to be at par with male students' enrolment in technical training institutions. Ex-post facto research design was used to carry out the study in public technical training institutions in Nyanza Region, Kenya. The study population involved 2,200 male and eight hundred (800) female students enrolled in science related courses, forty (40) Heads of Departments and eight (8) Principals in public technical training institutions in Nyanza Region, Kenya. The study used stratified sampling technique to sample both male and female students according to their years of study. The study further used simple random sampling technique to sample $30 \%$ of male and female students from their strata. On the other hand, the study also used purposive sampling technique to sample forty (40) Heads of Departments and eight (8) Principals for the study. Questionnaires and interview schedules were be used to collect data from the respondents. The instruments were validated by experts in the School of Education at Bondo University College and their comments were used to construct the final instruments. To ensure reliability of the instruments, the researcher piloted the instruments in two public technical training institutions; this helped to remove ambiguity, questions that were not soliciting expected results and those that were repeated. Questionnaires were issued to the respondents and interview schedules were conducted by the researcher. Data collected were analyzed through descriptive statistics e.g. content analysis, graphical analysis and qualitative analysis. Data was presented in form of tables and verbatim reporting. The study may help in formulating policies geared towards narrowing the existing inequalities in enrolment of female students in science related courses in technical training institutions; improve enrolment of girls in science related courses in technical institutions and may also contribute knowledge in the field of gender equality where further research on gender issues were be recommended by this study.

Keywords: Access; Technical Learning Institution; Gender ; Courses; Nyanza Region

\section{Introduction}

The female students' enrolment in science related disciplines has been low in all academic cycles in developing countries (UNESCO, 2003). Science and technology for all is about focusing on achieving equity. Science education offers knowledge and skills needed to empower students to achieve and control their lives as individuals and at societal level (Republic of Kenya, 2011). The long term goal in achieving equity is to eliminate disparities by ensuring equitable participation and performance of both genders in education system.

United Nations Educational Scientific and Cultural Organization UNESCO (2003) recorded that in Arab states, 35\% 
of students are women and that in India access to higher education is restricted to girls, while in Indonesia, there are fewer women in the college yet there are more 19-29 years old age group women than men in the country. In South pacific, girls are outnumbered 3:1 in all courses and 4:1 in degree courses. In Peru, women accounted for $42 \%$ in institutions of higher learning in 1981. In Finland, women tend to dominate in social science and humanities while men dominate in science courses. In France, participation of female is $40 \%$ in science courses and the under-representation of women in the traditional male fields of mathematics, engineering and technology is widely held to be the result of gender stereotyping. (UNESCO, 2008). In developing countries, broad spectrums of economic and social constraints create barriers to female entry into the realm of higher education. On the study of the Middle East and North Africa, Psacharopoulos (1985), noted that religion and socio-cultural traditions such as early marriages and child bearing and the unwillingness to expose girls, help to explain low participation in formal education and to get grades necessary for science related programs in the technical training institutions.

In Nigeria certain professions are associated with male and female in "male-labelled" profession are regarded as abnormal and vice versa (Imogie, 2007). Egbochuku (2008) noted that science transforms and builds individual capacity to acquire appropriate information skills and competencies for personal survival and the development of the society. The Millennium Development Goals of 2000, Education for All, Dakar goals and Beijing platform of 1995 have consistently placed emphasis on the importance of promoting gender equality in education and advancement of women (Woodward, 2002). Salman and Olamoye (2008) described the education of girl child as indispensable vehicle for national development. Gender inequality is pronounced in Africa where socio-cultural factors contribute to the achievements and attitude differences. In Tanzania, reports indicate that very few females qualified for admission into engineering and science programmes in tertiary institutions even after lowering of cut off points. (Bunyi, 2004).

The contribution of women is crucial if Kenya is to achieve and compete favourably in the world economy. Women are the educators of the young and their positive attitude and enhanced achievement in science related courses would boost the participation of their children, equally the girls. (Gerson, 1995 \& Wasanga, 2010). Students' enrolment in technical training institutions in Kenya by gender in the Republic of Kenya (2011) showed 7,500 males and 4,800 females. Of the total enrolment, female students constitute $30 \%$. Engineering courses attracted insignificant number of female students compared to males which was $20 \%$ higher. Conversely, student enrolment in the public technical training institutions in Nyanza Region recorded 17\% female enrolment in science related courses. According to Catsambis (2005), gender inequality in science and technology is a widespread phenomenon. Many intervention programmes need to be implemented to address the differences in enrolment in science courses by female students.

It is in view of the under enrolment among female students in science related courses that motivated the researcher to assess the factors which influence the enrolment of female students in science related courses in Nyanza Region, Kenya.

Science courses are essential for scientific and technological development of any country. Literature indicates low enrolment of female students in science related courses when compared to their male counterparts especially at the technical training institutions in Kenya. Kenya's Vision 2030 initiative aims at making the country a newly industrialized middle income country providing high quality life for all its citizens. The realization of this vision calls for the harnessing of science and technology ability of both men and women in the country. It is a collective responsibility of both genders. However, the vision may not be realized fully if females continue to under enroll in science related courses which are expected to spur industrialization, this development needs to be addressed. It is against this background that this study seeked to determine factors limiting female access to science related programs in technical training institutions in Nyanza region, Kenya.

The purpose of the study was to determine the factors that hinder female students' access to science related courses in public tertiary institutions in Nyanza Region, Kenya.

This study was guided by the following objectives: To determine the student factors that hinder enrolment of female students in science related programs. To assess institutional factors that influence the female access to science related programs in public technical training institutions in Nyanza Region, Kenya.To establish social-cultural factors that hinder female access to science related programs. To establish policy initiatives to promote female access to science related programs. 


\section{Research Methodology}

\subsection{Research Design}

Ex post facto research design will be adopted for this study. In such a design, research inferences about relationships among variables are made systematically and empirically without direct control of independent variables because their manifestations have already occurred and also because they are inherently non-manipulable. The design will be suitable for studying the factors that hinder female students' access to science related programs in public technical training institutions. It is also suitable for establishing the policy initiatives established to promote female access to science related programs. (Kerlinger, 2003).

Nyanza Region is found in Western part of Kenya. It consists of Kisii county, Homabay county, Migori county, Kisumu county and Siaya county. It is sandwiched by Western province to the South and Rift Valley province. Nyanza Region has eight public technical institutes namely Gusii Institute of Technology and Iterio Institute of Technology both in Kisii county, Moi Institute of Technology in Migori county, Mawego Technical Institute in Homabay county, Ramogi Institute of Advanced Technology (RIAT), Kisumu Polytechnic in Kisumu county, Nyang'oma Technical Training Institute, Siaya Institute of Technology in Siaya county and Kitere Technical Institute. Nyanza Region is predominantly Luos and Kisii community. The economic sources of livelihood are fishing, farming and commercial activities. It harbours major towns such as Kisumu, Siaya, Bondo, Homabay and Kisii. The Region falls within the latitude of $0^{\circ} 26^{\prime}$ to $0^{\circ} 18^{\prime}$ North and longitude of $33^{\circ} 58^{\prime}$ East and 34 $33^{\prime}$ 'West. The Region's contribution to National Poverty Index is 1.85\% (Republic of Kenya, 2002). The study population consists of 800 female students and 2,200 male students enrolled in science related courses from the eight public tertiary institutions in Nyanza Region. It consisted of students enrolled between 2010, 2011, 2012 ( $1^{\text {st }}$ year, $2^{\text {nd }}$ year and $3^{\text {rd }}$ year of study). Also included in the study was 40 Heads of Departments and 8 Principals.

According to Kerlinger (2003), 30\% of the entire population can participate in social research. Stratified and simple random sampling by use of table of random numbers was used to select 660 male and 240 female students for purposes of undertaking research.The simple random sampling was appropriate because it gives equal chances to all the respondents. All 40 Heads of Departments and 8 Principals were purposively sampled for the study.

Table 3.1. Study Population Sample Frame

\begin{tabular}{cccc}
\hline Category of respondents & Total Population & Number Sampled & Percentage \\
\hline Head Teachers & 8 & 8 & $100 \%$ \\
Heads of Departments & 40 & 40 & $100 \%$ \\
Female Students & 800 & 240 & $30 \%$ \\
Male Students & 2,200 & 660 & $30 \%$ \\
\hline
\end{tabular}

Questionnaires and interview schedules were used to gather information on factors influencing female access to science related courses. The study used three types of questionnaires namely: Student's Questionnaires, Head of Department's Questionnaires and Principal's Questionnaires as per the objectives of the study. The study also used one Interview Schedules to solicit more information from the respondents over the factors influencing their enrolment.

Reliability of the instruments was determined through split half technique. The instruments (questionnaire and interview schedule) items were split into two sub sets by placing all odd numbered items in one sub set and all even numbered items in another sub set. This means that the scores for each individual respondent were divided into two subset scores. Scores for all the odd and even number items for each of the respondents in the pilot study were computed separately. The odd numbered scores were correlated with even numbered scores. The Pearson product moment correlation coefficient was used to calculate the result. The value of $r$ was found to be 0.8 . Thus, the instrument was found to be reliable because the value of $r$ was more than 0.5 . In social sciences, acceptable reliability coefficient range from 0.6 to 1.0

Validity of an instrument is based on how an instrument fulfils the function it is supposed to perform, Kerlinger (2003). If the data collected is a true reflection of the variables, then the inferences based on such data will be accurate and of meaning. The research instruments were presented to three experts in the School of Education at Jaramogi Oginga Odinga University of Science and Technology for their scrutiny. Their advice on content was then used to improve the final copies of the instruments

The responses from open-ended questionnaires and interviews were transcribed, and then the transcript was coded. Responses to the close-ended questions was also coded. The coded data were then be grouped according to the 
research questions and analyzed using descriptive statistics, such as frequencies, percentages and means.

Five point likert-type scales were used to assess the perceptions of Principals, Heads of Departments and female students on the factors which limit the female students' access to science related programmes in public technical institutions. On the scale (SA) Strongly Agreed $=5 ;(A)$ Agreed $=4 ;(U)$ Undecided $=3 ;(D A)$ Disagreed $=2$; and $(S D)$ Strongly Disagreed $=1$. Pearson $r$ was used to establish the similarities and differences on the perceptions of principals and female students.

\section{Results and Discussion}

\subsection{Student Factors that Hinder Enrolment of Female Students in Science Related Programs}

The first objective was to determine the student factors that hinder enrolment of female students in science related programs. The research question responded to was: What are the student related factors that hinder female student enrolment in science related programs in technical training institutions in Nyanza Region, Kenya? The respondents were asked to rate the contributions of the stakeholders to quality leadership, their responses were as shown in Table 4.5.

Table 4.5: Students factors that hinder enrolment of female students in science related programs as reported by Principals $(n=8)$, Heads of departments $(n=40)$ and Students $(n=900)$

\begin{tabular}{|c|c|c|c|}
\hline Student attitudes that hinder female enrolment in Science related Programs & $\begin{array}{c}\text { Principals } \\
\text { Mean Rating }\end{array}$ & $\begin{array}{c}\text { HoDs } \\
\text { Mean Rating }\end{array}$ & $\begin{array}{c}\text { Students } \\
\text { Mean Rating }\end{array}$ \\
\hline Science courses are meant for boys not girls & 4.9 & 4.8 & 4.9 \\
\hline Science achievement at KCSE level gives a firm foundation for future development & 4.5 & 4.7 & 4.8 \\
\hline Higher education is for those with sound economic background & 4.2 & 4.5 & 4.6 \\
\hline Lecturers' attitude can inhibit or promote the students' ability to excel & 3.9 & 4.3 & 4.4 \\
\hline College environment is crucial in students' behavior and performance & 3.7 & 3.7 & 4.0 \\
\hline Pictures and photographs on the institutes' brochures are gender insensitive & 3.4 & 3.5 & 3.9 \\
\hline $\begin{array}{l}\text { Socio-cultural background of a student is an important factor to be considered during } \\
\text { college admission }\end{array}$ & 3.3 & 3.2 & 3.6 \\
\hline Output demands necessitates the supply & 2.9 & 3.0 & 3.4 \\
\hline KCSE is not a fair standard achievement & 2.4 & 2.6 & 3.0 \\
\hline
\end{tabular}

Table 4.5 reveals that student perceptions do highly hinder female enrolment in science related programmes in technical institutions. Perceptions that Science courses are meant for boys, science achievement at KCSE level gives firm foundations for future development, Higher education is for those with sound economic background and that lecturers' attitude can inhibit or promote students' ability to excel were all rated higher by all categories of respondents between 4.9 and 3.9 mean rating. Influence of college environment towards students' achievement and performance, brochures and pictures are gender insensitive, socio-cultural background of the student is an important factor during admission and output demands necessitate supply, and that KCSE is not a fair standard achievement were averagely rated between 3.7 and 2.4 by all respondents as shown on the table. The above finding concurs with (MOEST, 2003) that Tertiary Institutions do not significantly address the inequalities in the training sector especially with regards to gender differentiation in science related courses.

During interviews, the study established that most female students have the attitude that science courses are meant for boys as was maintained by all (100\%) principals who participated in the study. The principals further noted that most female students do give up on enrolling on science related and do influence others who would want to enroll in science related programme. According to most (98\%) heads of departments, most female students feel inferior to enrolling in science related programmes in tertiary institutions following their upbringing which was stereotype of male dominance on technical subjects. This finding concurs with (chege and Sifuna, 2006) that women are underrepresented in science subjects at secondary school level and that there is also the issue of gender stereotyping of science courses which is reinforced at earlier levels of education coupled with methodologies and content of technical education.

This finding concurs with Yahaya (1999) that sex stereotype and poor economic base are among the factors that militate against female. This finding also concurs with Imogie (2007) when the researcher observed that in Nigeria people associated certain professions with male and regard female in "male-labeled" profession as abnormal and vice versa. This finding also confirms the findings by (Chege and Sifuna, 2006) that in the male oriented departments such as Building and civil engineering, electronic engineering and mechanical engineering, female representation are particularly 
poor - comprising $6.3 \%, 3.4 \%$ and $2.7 \%$ of student population respectively.

Science achievement at KCSE level gives a firm foundation for future development. This was also explained by the principals to be very vital as it affects female enrolment into science related programmes in the tertiary institutions of science and technology. Most (87\%) principals further explained that it was hard to improve on female student enrolment into science related programmes as they do perform poorly in science subjects at KCSE examinations which in turn was being used in admitting students into science related programmes at the institutions.

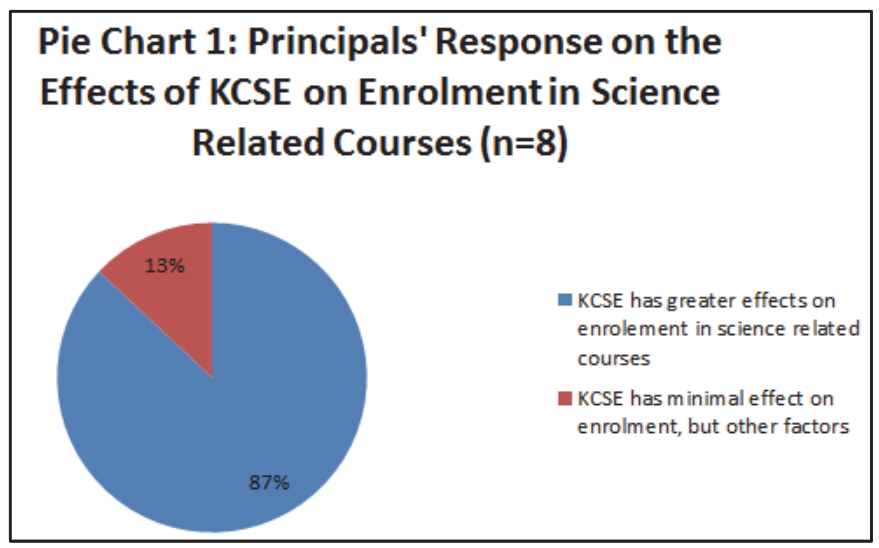

Heads of Departments on their part blamed the poor attitude developed by the learners at formative stage in secondary schools which makes them to perform poorly in science subjects at KCSE. Some (67\%) heads of departments blamed the career guidance at secondary school level which they noted were not advising the students well in advance on the importance of taking science subjects seriously at that level. The heads of departments emphasized that the foundation offered by science subjects at KCSE level was mandatory as what were being taught at tertiary level was progressing on the earlier foundation developed at the basic level.

Students also concurred with their teachers that Science achievement at KCSE level gives a firm foundation for future development at tertiary level. Most (98\%) students testified that without proper foundation at secondary schools level, it was difficult for the students to enroll in science related programmes at the tertiary levels. Some (65\%) students further agreed with their teachers that most female students fail to enroll in science related programmes because they were not offered adequate career guidance at secondary level as such did not put much efforts in science subjects at KCSE examinations.

Higher education is for those with sound economic background. This statement was supported by principals during interviews as they noted that most students do avoid science related programmes because of lack of funds to pay for extra levies that goes along with expensive practical lessons associated with such programmes. Most (89\%) principals noted that most students who qualify for science related programmes do fail to enroll in them because of lack of funds by the learners. This is why most of the institutions have adopted affirmative action of sponsoring female students who have higher entry level in science related programmes.

According to heads of departments the demands by the curriculum of science related programmes at tertiary level are so high that the institutions are forced to charge more from the students who are taking such programmes. The heads of departments also echoed the sentiments of the head teachers that most students were forced to abandon science related programmes due to lack of funds. They further noted that only those who could afford the levies were the ones enrolled hence the smaller number enrolled in such programmes.

On their part, students blamed the institutions for unfair charges in science related programmes which to them was only meant to limit the number of those with interest in enrolling in science related programmes. The students also noted that the most marketable programmes were meant for the students from sound economic background as prices of books required were so high for those with low economic background to afford.

Lecturers' attitude can inhibit or promote the students' ability to excel. This sentiment was only supported by some (67\%) principals who noted that some teachers indeed do have formed opinion about some students and this they noted were scaring learners especially female students. The principals further noted that due to professional ethics, the lecturers were very positive towards the students and this they noted was leading to good performance.The other (33\%) principals however did not agree with the sentiment noting that lecturers were acting "in loco parenties" to the students as 
such were treating the learners equally while they were in the colleges.

Most (79\%) Heads of departments agreed with the sentiment and explained that they have several cases where students report their lecturers for favoring some learners at the expense of other learners taking similar science related programmes. The other $(21 \%)$ concurred with the principals that lecturers were very professional people hence were handling the students equally. These heads of departments however blamed the students for not being ready to work hard which is paramount for those who enroll for science related programmes.

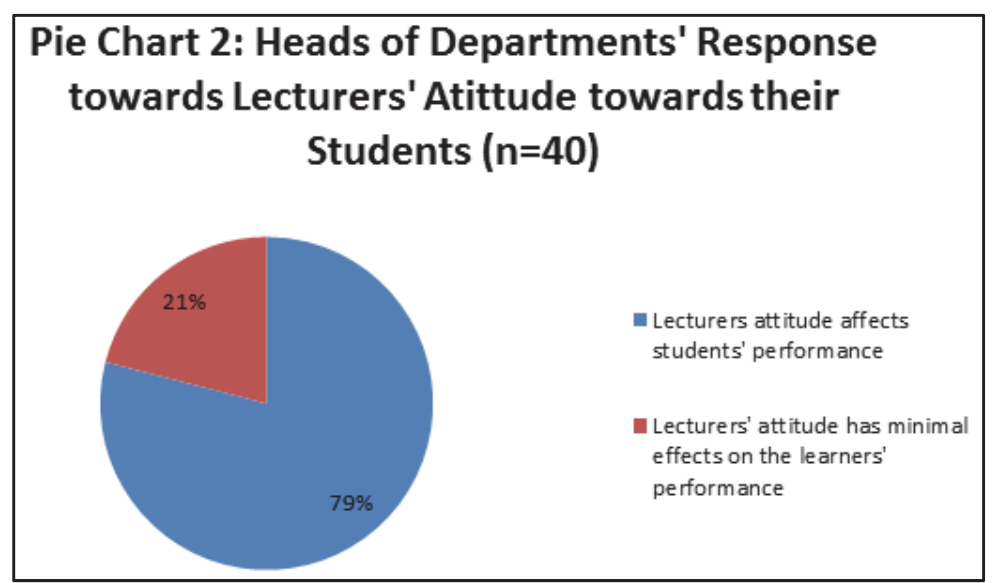

Most (97\%) students supported the sentiment that lecturers' attitude can inhibit or promote the students' ability to excel. Most (78\%) students maintained that the negative attitude towards them from lecturers was due to poor teaching methods which when they question was leading to poor relations with the lecturers. Some (22\%) students however blamed the students for the negative attitude formed against them by lecturers citing cases of students who do not attend classes regularly. They added that most students were lazy and when the lecturers become serious with their assignments and examinations, they blame the lecturers for having negative attitude towards them.

College environment is crucial in students' behavior and performance which sentiment was well supported by principals during interviews. All (100\%) principals agreed during interviews that the college environment was affecting the learners as they were experiencing free environment compared to their previous school life. The principals further noted that students tend to feel relaxed and do not want to enroll for science related programmes which demanded them to read most of the time while their colleagues were relaxing hence low enrollment for female students. Peer pressure was also cited to be affecting enrollment in science related programmes.

Most (96\%) heads of departments also supported the sentiment citing free life of less control, peer influence and self discipline to be affecting female student enrollment in science related programmes. Some students with free atmosphere do become self conceited and fail to pass their examinations hence change to arts based programs or they dropout.

Most (78\%) students acknowledged that the college environment was affecting their choice for science related programmes. The fact that they were given freedom which was lacking at secondary schools made most of the students to be lazy and were not willing to work hard. The students added that college life was demanding as they were required to budget for their meals which they were not used to. As such most of them were misappropriating their pocket moneys and were not able to concentrate in their studies, this result into students opting for programmes that were less taxing.

Pictures and photographs on the institutes' brochures are gender insensitive; this sentiment was only supported by half of the principals who participated in the study. The principals noted that this was not true as the photographs on the brochures were from the various classes where both gender were represented. The principals who supported this sentiment maintained that most of the pictures of students in science related programmes were of male students as such female students were being discouraged from taking science related programmes. 


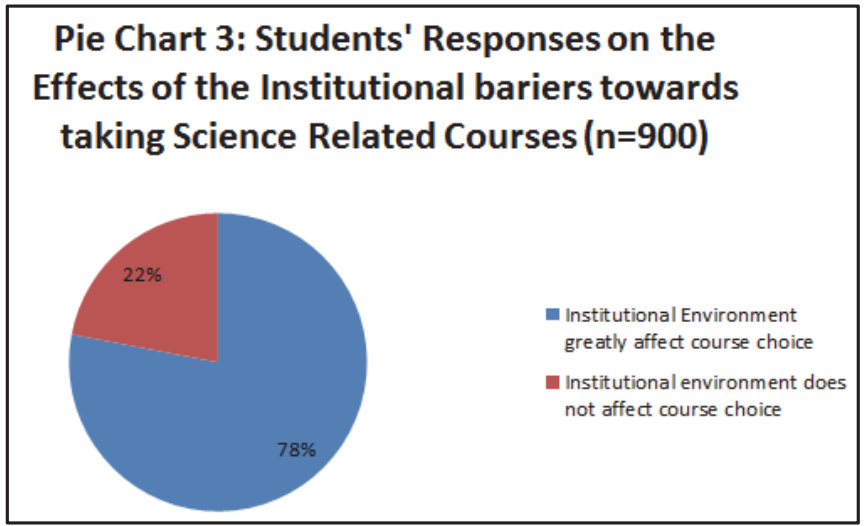

Most (78\%) heads of departments did not support the sentiment that the pictures and photographs on brochures were gender insensitive. They maintained that their departments do ensure that there was gender balance on the photographs approved for usage on the brochures, calendars and institutional magazines. However some (22\%) heads of departments noted lack of gender sensitivity on the photographs used by their institutions. This they noted was depicting wrong pictures to female students who appeared as under dogs in the science related programme classes.

The students were equally divided on supporting this sentiment. Some (65\%) students noted that the pictures and photographs used by institutions do not appeal much to their career choice or programme selection. These students further argued that they do make their choice earlier before going to the institutions for admissions. The other (35\%) students on their part maintained that some students do make their programme choices after getting proper orientation and career guidance from the college counselor. This group of students maintained that their decisions were being affected by the photos and other visible things they could come across in the institutions about the programmes they were to enroll in.

Socio-cultural background of a student is an important factor to be considered during college admission. This was supported by most (87\%) principals who maintained that socio-cultural background would help the institutional management to determine who among the learners deserve scholarship or bursary. The principals also noted that this factor was vital for establishing if the students were suffering from any disease that would deter them from enrolling for certain programme. The other (13\%) head teachers noted that the student socio-cultural background was not very vital for programme enrollment apart from the administration records.

Some (57\%) heads of departments on their part maintained that the students' socio-cultural background was vital for programme selection by the students. They noted that socio-cultural background would reveal the financial capability of the students which would help in advising the students on the programmes they could afford. The socio-cultural background could also help the departments to advice the students as per their aspirations which usually emanates from the social background. They also noted that socio-cultural background do influence individual character traits hence was vital for administration of discipline among the students enrolled in the departments. Most (76\%) students also agreed that their socio-cultural back ground was vital for their admission as it helps the institutional administration to understand why they would want to enroll for certain programmes. Some (24\%) students however did not support the sentiment arguing that socio-cultural background was irrelevant to what the student would want to pursue for their future careers.

Output demands necessitates the supply was supported by some (65\%) principals who maintained that market of programmes must be taken into consideration and students must be well advised before being enrolled for the programmes. These principals further noted that students were enrolling highly in programmes which are marketable as compared to those which were not having ready job demands. The other (35\%) principals felt that all programmes offered by the institutions were marketable and only depends on the performance of the individual students. They argued that before the institutions start offering certain programmes, they had to first consider its market demands as such all programmes offered in the institutions were marketable.

Most (89\%) students supported the sentiment of output demands necessitates the supply, arguing that some programmes are outdated and were no longer marketable in the job market. The students further noted that there were some programmes that their recipients have been jobless for years since they completed them. Most students therefore over enroll in certain programmes and leave other programmes in the colleges and least enroll on others perceived to be less marketable. A few (11\%) students on their part felt that individual performance matter more for the job market than the type of programme taken. 
KCSE is not a fair standard achievement. This was not supported by most (89\%) principals who maintained that KCSE was fair as those students who failed in certain subject areas related to various programmes do fail to pass in such programmes when they enroll for them at the college level. The principals further noted that students performance at KCSE were giving the correct entry level of the students to various programmes as such institutions do peg entry level of their programmes to various performance at KCSE achievements.

Majority (94\%) heads of departments also disagreed with the sentiment during interviews. They asserted that KCSE standards were very relevant for enrolling learners in various programmes as it rates the students. The heads of departments further maintained that they had good experience of the student exhibiting relations between their KCSE achievements and their performance in various programmes at college level. The other (6\%) heads of departments however supported the sentiment noting that in some programmes like Accounting, students do enroll without prior performance at KCSE but do excel on such programmes. They then alluded that what matters is the commitment of the learners towards the programmes they had enrolled in than their achievement at KCSE.

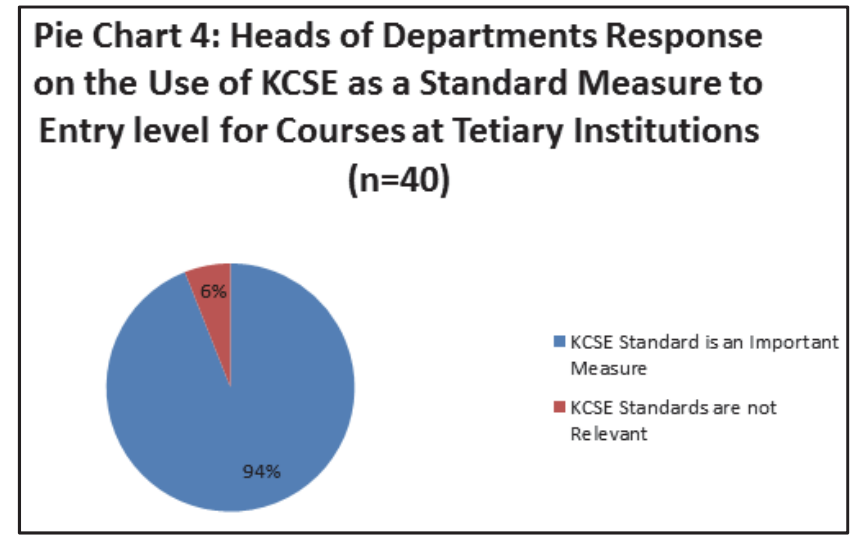

Some (65\%) students also disagreed with the sentiment arguing that background standards offered at KCSE was vital for their programme selection at college level. These students further asserted that most of the students do value the standards at KCSE as it was used by various institutions of higher learning as the yardstick for enrolling in various programmes. The other (35\%) students supported the sentiment by noting that KCSE examinations do take shorter period but test all that has been studied for the past four years hence does not give the exact standard performance of a student. This group of students preferred the use of Continous Assessment Test to give the true standard of the students that may be reliable for enrollment in a programme at the college level.

Institutional Factors that Influence the Female Access to Science Related Programs in Public Technical Training Institutions in Nyanza Region, Kenya

The second objective was to assess institutional factors that influence the female access to science related programs in public technical training institutions. The research question responded to was: What are the institutional factors which influence the female access to science related courses in tertiary institutions in Nyanza Region, Kenya?

Table 4.6: Institutional factors that hinder enrolment of female students in science related programs as reported by Principals $(n=8)$, Heads of departments $(n=40)$ and Students $(n=900)$

\begin{tabular}{lccc}
\hline $\begin{array}{l}\text { Institutional Factors that Influence the Female Access to Science Related } \\
\text { Programs }\end{array}$ & $\begin{array}{c}\text { Principals } \\
\text { Mean Rating }\end{array}$ & $\begin{array}{c}\text { HoDs } \\
\text { Mean Rating }\end{array}$ & $\begin{array}{c}\text { Students } \\
\text { Mean Rating }\end{array}$ \\
\hline Poor science facilities like laboratories and equipments, text books & 3.2 & 4.9 & 4.9 \\
Lecturers attitude towards ladies enrolled in science related programs & 3.2 & 4.7 & 4.9 \\
Discouragement from peer pressure & 2.7 & 4.6 & 4.8 \\
Teaching methods that are more of theory than practical & 2.4 & 4.4 & 4.6 \\
Inadequate text books for research and exercise & 2.1 & 4.4 & 4.5 \\
Lack of regards during practical & 2.0 & 4.1 & 4.3 \\
Inadequate qualified teachers hence lack of in-depth syllabus coverage & 1.7 & 3.7 & 4.2 \\
Inadequate time allocated for practical lessons & 1.5 & 3.5 & 4.1 \\
Lecturers discouraging more students from taking science related programs & 1.2 & 3.4 & 4.0 \\
\hline
\end{tabular}


Poor science facilities like laboratories and equipments, text books, Lecturers attitude towards ladies enrolled in science related programs, Discouragement from peer pressure and Teaching methods that are more of theory than practical were highly rated by the participants who filled the questionnaires.

Poor science facilities like laboratories and equipments, text books was highly noted by most (97\%) Principals during interviews to be a major institutional factor that influence female students access to science related programmes. They noted that inadequate books for revision and research do compel the institutions to request the students to buy such books especially science related programmes. Such demands do hinder students access as they opt for arts related programmes where books were either not needed or minimally required. The principals further noted that inadequate laboratory facilities do require creativity from the learners most of which were only performed by male students hence hindering female access to science related programmes.

Most (94\%) Heads of departments also maintained that inadequate facilities in the institutions was a great hindrance not only to female students but also to all students as the departments were forced to limit the number of students to be admitted into science related programmes. The inadequate facilities like laboratories meant much efforts to be put from the students, such demands of hard work do favour male students while female do feel such programmes best suit male and not female students.

During interviews with the students, the study established that inadequate facilities were a major stumbling bloc to their access to science related programmes. Majority (95\%) Heads of departments noted that making the entry levels to be raised by the institutions as such reducing the student numbers in science related programmes. The students further maintained that many a times they were offered theory training with very minimal practical lessons which do make many students opting for other programmes.

Lecturers attitude towards female students enrolled in science related programs was seen by most (87\%) principals as a hindrance to their enrollment. They maintained that some lecturers do have low opinion on female performance on science related programmes as such do discourage them from enrolling into science related programmes. Some (13\%) principals however noted that most students do not comply with the requirements of various programmes and end up blaming the lecturers for having formed attitude towards them.

Most (86\%) heads of departments also concurred with majority of their principals that attitude of some lecturers together with their methods of teaching do affect female enrollment in science related programmes. The heads of departments further indicated that how a lecturer handle the programme units matters a lot for the learners especially female students who are always keen in noting the way they are taught. Failure by lecturer to give proper explanation on an issue is enough to put the female students off balance and would lead to mass exodus from the programme or unit.

Most (94\%) students also agreed that some lecturers do hinder students from registering for a programme. They explained that on arrival at the colleges students were always informed by their peer the character of lecturers teaching different units of various programmes. The students added that attitude of lecturers are adequately discussed during informal induction and orientation usually done among student body. The students especially female do fear such character and do request for programme change even before they start learning or registering for the units.

Discouragement from peer pressure was noted by some (70\%) principals to be taking place among the student community. The principals explained that students do discourage each other from taking certain programmes especially science related for fear of taking re-sit when they fail to meet the pass mark during examinations. Peer pressure was also noted to be taking toll among the female students who enroll for science related programmes but did not perform well in mathematics at KCSE. The pressure from peers was always making the female students to fear the college atmosphere and was always leading to poor performance.

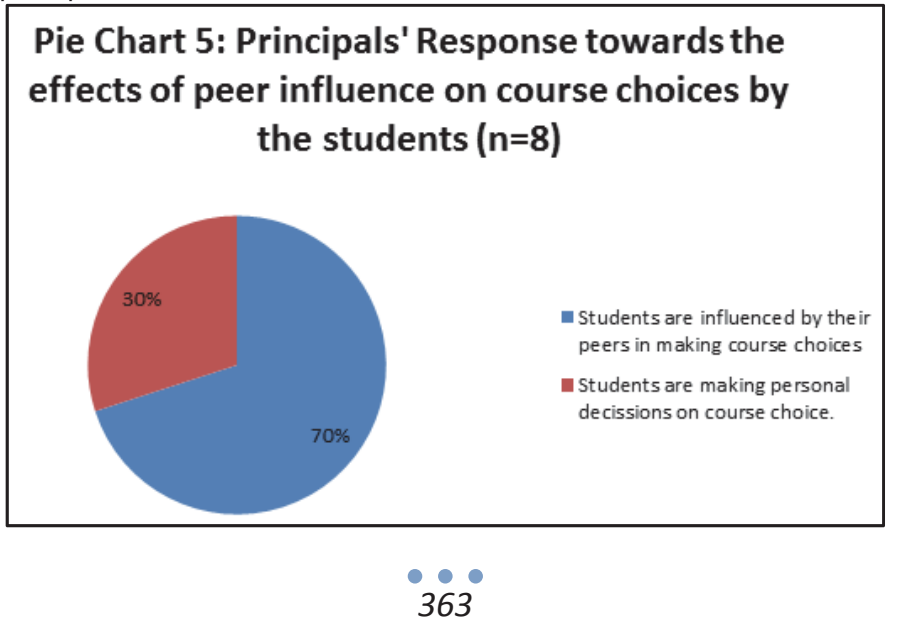


Heads of departments just as their principals also noted that peer pressure was really affecting female students from taking the programmes they had initially applied for. They noted that due to pressure some students do leave some programmes after going half way to enroll for other programmes especially during the first semester. Peer pressure they noted was also making students to demand to change to other programmes which they either had not qualified for or were unable to do. All (100\%) heads of departments noted that they are always forced to handle a lot of cases and offer career guidance to the learners who are being misled by their student colleagues to abandon the programmes they had been admitted for.

Most (87\%) students agreed that peer pressure do affect their programme and unit selection at the college. The students also maintained that peer pressure do make them perform poorly as they would want to feel part of their colleagues and thus do not concentrate on their studies. The students added that they at times are forced to run away from their initial programmes to other programmes when they realize they could not balance between peer pressure and programme demands.

Teaching methods that are more of theory than practical was acknowledged by most $(68 \%)$ principals. They further noted inadequate facilities for practical lessons. The principals also noted the nature of the curriculum and syllabus which in most cases had more theory lessons than practical lessons. The other (32\%) principals blamed the unprofessional lecturers who were not willing to conduct practical but refer the students to conduct the practical lessons with laboratory attendants, in turn learners do not take such instructions hence fail to do practical lessons.

Most (73\%) heads of departments maintained that teaching methods were adequate given the level of the learners and the nature of the programmes offered. They however blamed the low entry level of grade $C$ which makes the students unable to cope with teaching methods at college level. The heads of departments also noted the inadequacy of materials for teaching practical lessons. They maintained that all those factors together with lack of self esteem from the learners were leading to the misconception that teaching methods were of substandard level at the institutes of technology.

Most (77\%) students however differed with the heads of departments noting that most lecturers were not conversant with the content of the units they were teaching, not committed to attending their lessons while some were group discussion throughout the units they were taking. The students further noted that lecturers were copying certain books directly and giving them inform of lesson notes as such were not giving them wider perspectives of the units they were taking. Some (23\%) however did not support the sentiment noting that the teaching methods were adequate and that at college level students were to conduct practical lessons with laboratory technicians which most students do ignore.

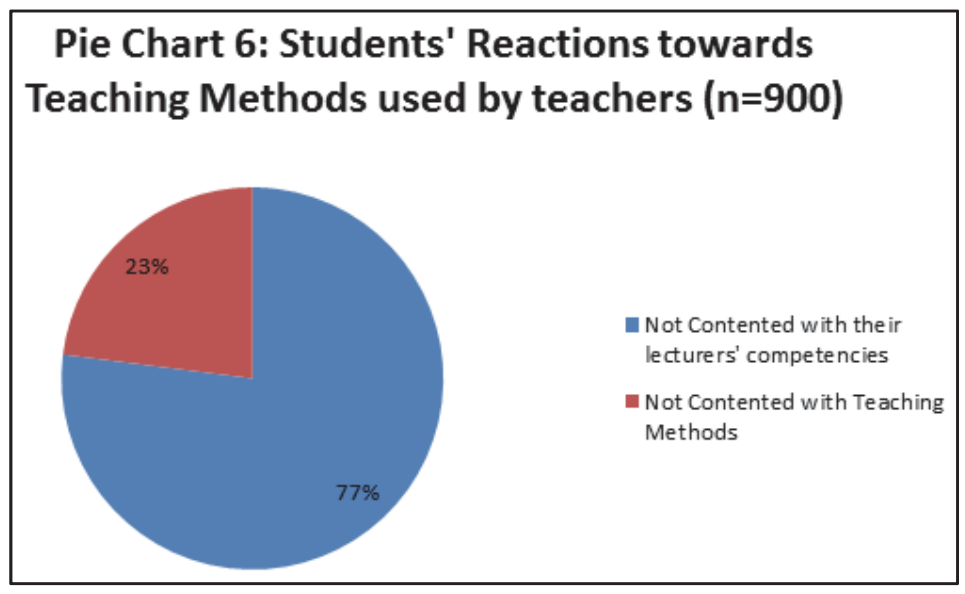

Inadequate text books for research and exercise was noted by all (100\%) the principals during interviews but they turn the blame on low capitation received from the Ministry of Higher Education by Tertiary Institutions. The principals however maintained that their institutions had e-library and that serious students could do their research well through internet which was available in the libraries.

Most (89\%) Heads of departments acknowledged that their departments were not having enough books for research and exercises. They argued that the principals had not given priority to books but were concentrating on the physical facilities in order to attract more students. Some (67\%) heads of departments maintained that yearly they serve their administration with list of relevant books but the administration keeps on promising to buy which they end up not 
buying. Some (11\%) heads of departments however noted that although their institutions lacked books in hard copy, most of the relevant books were in their e-library and this is line with modern library systems all over the world.

All (100\%) students noted during interviews that their institutes were lacking research and other reference books. They maintained that at times they were not able to do the assignments or research work because of inadequate books. Some (67\%) students maintained that their institutions were having out dated books which could not help in research work. A few (33\%) however maintained that although they lacked books, their colleges had e-library and free internet services which make them not to have problems during research or private studies.

Lack of regards during practical was noted by all principals as just a misunderstanding of the learners at college level. Most (78\%) principals maintained that practical lessons at college level were supposed to be handled by laboratory technicians and not the lecturers. The feeling of the students was a misconception which was a practice at secondary school level. These principals however noted that there could be laxity from the part of the lecturers and laboratory technicians.

Most (89\%) heads of departments noted that most lecturers were not committed to organizing for practical lessons. They further revealed that they had been having difficulty with lecturers to which they have been forced to write warning letters to some lecturers. The heads of departments also blamed the laboratory technicians who were also reluctant to conduct practical lessons with the students after the lecturers had given them instructions on how to organize and conduct practical lessons on various units. The heads of departments also differed with the principals whom they accused of not availing chemicals and other equipments for practical lessons on time .

Most (76\%) Students concurred with the heads of departments over laxity of the laboratory technicians who were not ready to conduct practical lessons after being instructed with the lecturers. Some $(56 \%)$ students however blamed the general administration for being reluctant in buying chemicals and concentrating on physical facilities of the institutions. The students also noted inadequate laboratories with expired chemicals that were in the institutions making it difficult for performing successful practical lessons.

Inadequate qualified teachers hence lack of in-depth syllabus coverage was noted by most (78\%) principals who blamed the Ministry of Education for the shortage after the ministry had imposed a ban on recruitment of new lecturers in colleges five years ago. The principals further maintained that they have been forced to hire part-time lecturers so as to keep the programmes running. They further reiterated that these lecturers had qualifications on various fields and that heads of departments were ensuring that quality was not compromised.

All (100\%) heads of departments maintained that there was lecturers' shortage in various fields of study. They however noted that they were forced to keep on hiring part-time lecturers who keep on changing due to greener pasture or getting full employment, such situation they noted was causing hitch on syllabus coverage. Most (77\%) heads of departments however maintained that they were in control of their departments and they were ensuring that syllabus was well covered and students were offered quality service.

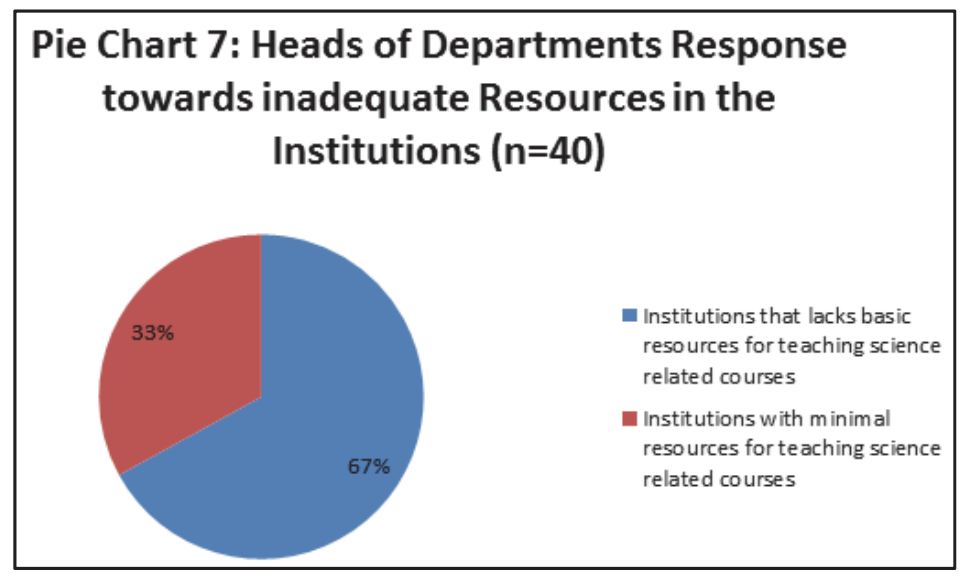

Most (88\%) students maintained that most of the part-time lecturers were not qualified in the areas where they were made to teach. Some they noted were not having course outlines for the units they were teaching. Others they noted were teaching less than one hour which they were supposed to take per unit teaching. Some (65\%) further maintained that they do not complete the topics in the course outlines yet they were to sit Kenya National Examination with the rest of Kenyans in other tertiary institutions. 
Inadequate time allocated for practical lessons was not supported by the principals who explained that all lessons had been allocated enough time as per the curriculum of the tertiary colleges. All (100\%) principals were able to refute this sentiment and noted that in case of missed practical lessons, and then the laboratory technicians were to blame for this. Most (89\% heads of departments also concurred with their principals that enough time was allocated by their institutional time table committee for all practical lessons as such there were no inadequacy on the time table allocation of practical lessons.

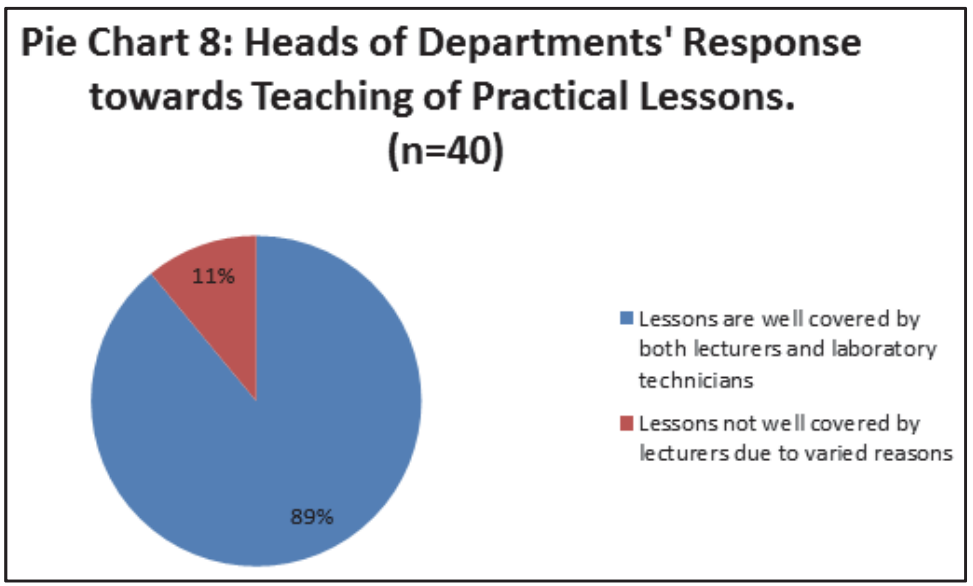

Some (64\%) students maintained that their timetables were having limited time for practical lessons and were feeling that their institutions were not fair to them. Some (36\%) students however noted that they had enough time allocation for practical lessons but they were only attending such lessons occasionally not as they appear on the timetable. All (100\%) students however maintained that they were not covering enough time for practical lessons as was supposed to.

Lecturers discouraging more students from taking science related programs. This was not supported by all (100\%) principals during interviews. The principals maintained that lecturers were professionally qualified and were observing professional ethics hence could not discourage students from taking science related programmes. All heads of departments also concurred with their principals as they observed that lecturers were encouraging most students to take science related programmes as such were aware of the impact of reduction in number of students in their units. Some (65\%) heads of departments however acknowledged having dealt with cases of students' complaint over lecturers sending them to other programmes for failing to meet the pass mark during their first entry examinations.

Most (78\%) students supported the sentiment that lecturers were discouraging students from enrolling into science related programmes. Some (56\%) students explained that they were affected by the lecturers who felt they could not perform well in science related programmes yet they were admitted in those colleges to undertake such programmes. The other (44\%) also narrated how some of their colleagues were affected and left the science related programmes they were initially admitted for because of the discouragement from the lecturers. The findings above concurs with Bannet, (2002) when the researcher observed that majority of Tertiary Institutions in Africa do not have any form of gender policy let alone interventions to increase female students enrolment. Further, where interventions are being implemented, little in the available literature shows that the impact of interventions are making is being measured or even the details of what the interventions entail and the process through which they are being designed and implemented.

\section{Social-cultural Factors that Hinder Female Access to Science Related Programs}

The third objective was to establish social-cultural factors that hinder female access to science related programs. The research question responded to was: What are the social-cultural factors that hinder female access to science related programs? The respondents were asked to rate the contributions of the stakeholders to quality leadership, their responses were as shown in Table 4.7. 
Table 4.7: Socio-cultural factors that hinder female access as reported by Principals $(n=8)$, Heads of departments $(n=40)$ and Students $(n=900)$

\begin{tabular}{|c|c|c|c|}
\hline $\begin{array}{l}\text { Social-cultural Factors that Hinder Female Access to } \\
\text { Science Related Programs }\end{array}$ & $\begin{array}{l}\text { Principals } \\
\text { Mean Rating }\end{array}$ & $\begin{array}{l}\text { HoDs } \\
\text { Mean Rating }\end{array}$ & $\begin{array}{c}\text { Students } \\
\text { Mean Rating }\end{array}$ \\
\hline Belief that science is difficult for girls but easy for boys & 3.2 & 4.9 & 4.8 \\
\hline Poor economic background & 3.2 & 4.7 & 4.8 \\
\hline Lack of parental guidance & 2.7 & 4.6 & 4.7 \\
\hline Belief that ladies are weak and cannot perform well in science related programs & 2.4 & 4.4 & 4.6 \\
\hline Lack of job opportunities & 2.1 & 4.4 & 4.5 \\
\hline Early pregnancy hinders as the ladies resort to arts courses that takes shorter periods & 2.0 & 4.1 & $4 . .0$ \\
\hline Tradition hinder women from putting on attires for science related programs & 1.7 & 3.7 & 3.8 \\
\hline Peer pressure that is against ladies taking science related programs & 1.5 & 3.5 & 3.7 \\
\hline Lack of role models of ladies who have excel in science related programs & 1.2 & 3.4 & 3.5 \\
\hline
\end{tabular}

Belief that science is difficult for girls but easy for boys, poor economic background, lack of parental guidance, belief that female students are weak and cannot perform well in science related programs and lack of job opportunities were highly rated from the questionnaires

While, Early pregnancy hinders the ladies as they resort to arts courses that takes shorter periods, tradition hinder women from putting on attires for science related programs, Peer pressure that is against female students taking science related programs and lack of role models of female students who have excelled in science related programs were rated low by all respondents who filled the questionnaires.

During interviews, belief that science is difficult for girls but easy for boys was noted to be a major socio-cultural factor hindering female students from taking science related programmes by all (100\%) principals. They further maintained that they were having it difficult to convince female students to enrolling for science related programmes because they join college with set mind of not taking science related programmes. Most (78\%) principals noted that they were forced to develop an influential team of career counselors during new admission periods to help in convincing female students into taking science related programmes.

According to all (100\%) heads of departments the belief that science is difficult for girls but easy for boys was a major problem in the tertiary institutions. The heads of departments further noted that most female students fear some science related programmes which usually force them to counsel the students when they want to transfer to other arts based programmes. The heads of departments further explained that most female who are capable of excelling in science related programmes do fail to do so because of the belief that were developed on them from the formative stage at primary school levels and as they join the tertiary level they develop fear which culminate into weak performance where they could have done better. This finding is in agreement with Kahle and Meece (1994) who observed that it is not that girls cannot and do not have the ability to succeed in science

Most (88\%) students conceded that they have the belief fully developed on them and that any science related programme was associated with calculations or mathematics which they fear most. Some (65\%) students felt that at college level it was hard to stop the fear because by then the belief had caused the damage of poor performance. It was only a few (22\%) female students who noted that they had outgrown the belief and were not seeing the difference between sexes especially in terms of academic performance. This finding is in congruent with Stan (2007) that gender inequality in science and technology is pronounced in Africa where socio-cultural factors contributes to achievements and attitude difference.

Poor economic background was noted as a hindrance to female students' access to science related programmes as was reported by most (73\%) principals. Poor economic background does hinder the female students from going to schools where they could be given better basics for science related programmes. They maintained that female students were unable to attend good schools as such were landing on programmes that were arts based at tertiary institutions. 


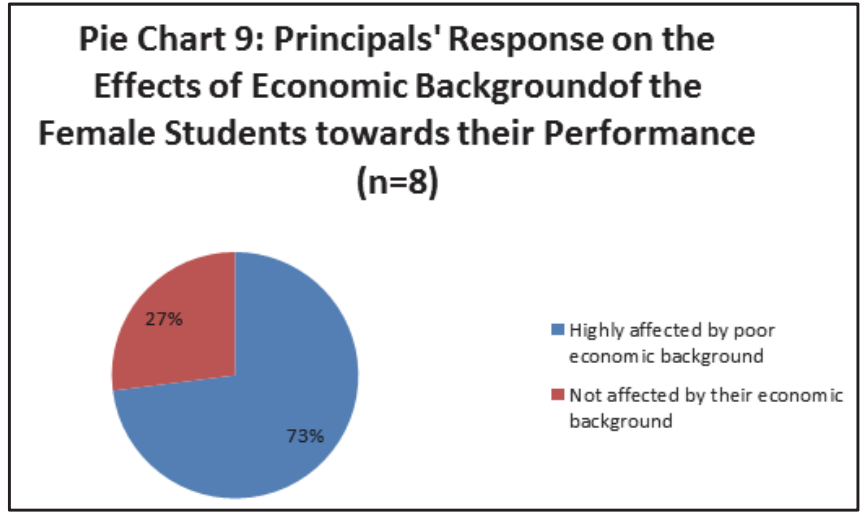

According to most (86\%) heads of departments, students from poor economic background though trying to cope with requirements of science related programmes, were unable as they could not afford extra fee required from students taking science related programmes. Some students from poor economic background could not buy the text books needed from the students of science based programmes. They argued that most students from poor economic background were disadvantaged as they attended schools that never offered them good basics needed to enable them understand the concepts at higher levels in the colleges.

Most (89\%) students were in agreement with their lecturers and principals that poor economic background was a hindrance to their access to science related programmes. They maintained that most of them were not able to meet the cost of science related programmes as much as they were willing to take the programmes. Some (66\%) students maintained that they were forced to seek admissions for arts related programmes while they had qualified for science related programmes simply because they were unable to meet the fee and other costs required for science based programmes.

Lack of parental guidance was noted by most (87\%) principals to be a hindrance to female access to science related programmes. The principals noted that students who were not guided by their parents do end up enrolling in programmes that are arts based on grounds that they were lighter and less demanding compared to science related programmes. The principals further noted that most students who were admitted in science related programmes had been guided by their parents. The principals therefore noted that parental guidance was very vital for the students to pursue better programmes.

Most (78\%) heads of departments noted that students who lacked parental guidance were not confident of the programmes they enrolled in and constantly wanting to change to other programmes. The heads of departments further noted that it was hard for them to settle students who were not guided by their parents as they were not sure of what the lecturers were advising them to take. All (100\%) students concurred with the sentiments of their lecturers as they noted that some of their parents were ignorant of what programmes were offered at the colleges. Some (63\%) students maintained that they were never advised on the programmes to take as such relied on their lecturers' and peers' advice.

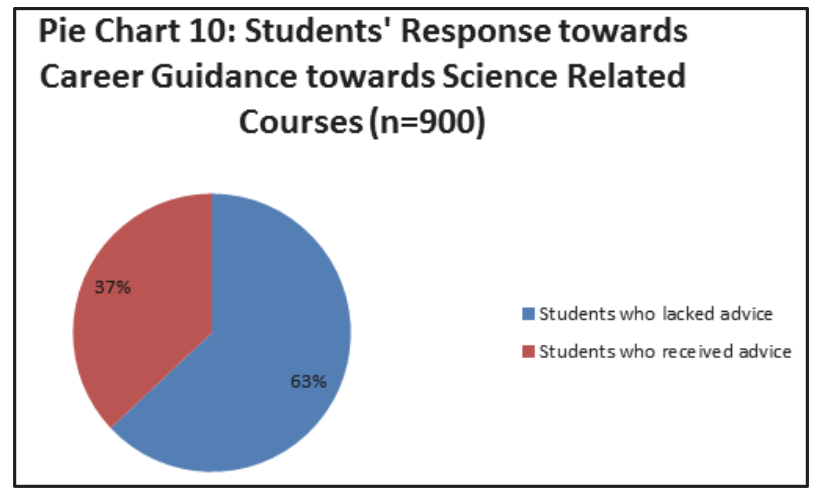

Belief that female students are weak and cannot perform well in science related programs was supported by most (68\%) principals. The principals noted that this belief was still in the mind of some female students at the college level. They 
added that such students were difficult to advice as they had fixed notion against certain programmes. On their part, only some (56\%) heads of department noted that the belief was affecting some students in their departments. They further maintained that only students who were not focused were the ones holding on such beliefs. The heads of departments however noted that they were doing all that is possible in their colleges to ensure that students were enlightened so as not to continue with such opinions which they described as retrogressive.

Only a few (25\%) students held the belief that female students were weak and could not perform better in science related programmes. The students further acknowledged the role played by their lecturers during induction where equality of sexes was emphasized. This they noted made some of them who were fearful from home to change their initial attitudes. The other $(75 \%)$ students did not hold the belief of female students being weak as they were embracing the equality of humanity in all aspects of life.

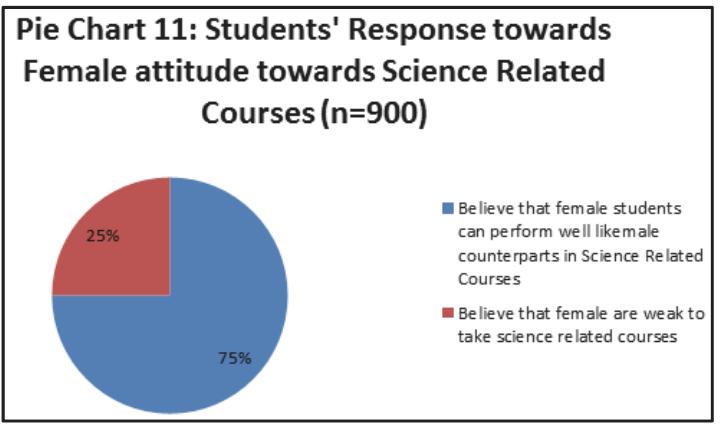

Lack of job opportunities was identified by some (45\%) principals as a contributory factor that hinders female access to science related programmes. This they noted was affecting students who had relatives who had done science related programme such as water engineering and veterinary medicine and were still unemployed. Most (79\%) heads of departments maintained that lack of job opportunities was a major hindrance as many students had enrolled on science related programmes and were unemployed. This they noted was disheartening to the prospective students and registered students who are turning to arts related programmes.

Lack of job opportunities was also hailed by most (89\%) students that it affects their ambitions with science based programmes. The students further noted that flooding of the trained unemployed people was making them to opt for programmes like social work service and accounting programmes which were less demanding but were also having job opportunities. Some (11\%) students however did not have any problem with unemployment as they noted that with knowledge, there was no wastage and opportunities were always available for those who perform excellent or well.

Early pregnancy hinders as the female students resort to arts courses that take shorter periods. This was seen by all (100\%) principals as not a big problem as in college they were not barred from attending lessons while pregnant. Most $(92 \%)$ principals further noted that pregnant students were not offered accommodation only after delivery as such this situation could not affect their learning. According to most (87\%) heads of departments, early pregnancy do affect females from pursuing science related programmes because it affects them as such do not perform well at KCSE which finally is used to admit students to various programmes. Some (13\%) heads of departments however noted with reservation that with the policy of equity education, early pregnancy was having minimal effect on the female student access to science related programmes as they still have the opportunity to pursue their career after delivery.

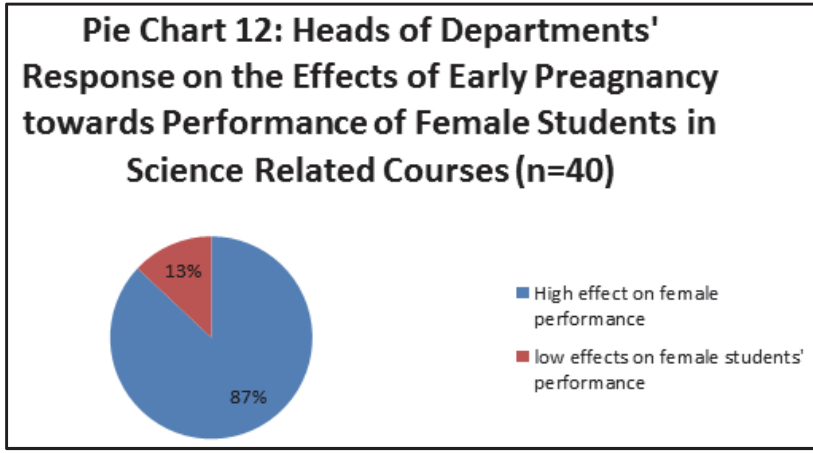


Most (76\%) students maintained that most of their colleagues were not able to join colleges because they did not perform well in the previous levels due to early pregnancy. Some (42\%) students noted that early pregnancy do affect the ambitions of female students as some were unable to continue with education after delivery while others who continue with education could not perform well as they would have done before. This therefore land them in low level programmes.

Tradition hinder women from putting on attires for science related programs, this was noted by some $(46 \%)$ principals to be mostly affecting female students from rural areas where such traditions are still held. The principals further maintained that students from urban set up were used to wearing attires like long trousers and short trousers hence were comfortable when the nature of their programme required them to do so. According to some (35\%) heads of departments the students who were still held in such tradition were difficult to convince and do take them some time to make them realize that there was no difference. The other (54\%) heads of departments did not see this as a major problem hindering the female students from taking science related programmes. Most (87\%) students equally did not see the tradition as a hindrance because they were out of touch with such traditions. To some (13\%) however it was a great issue for girls to even put on a long trouser and to climb a roof in case of electrical engineering. They further noted that they could not enroll on programmes that could render them outcastes from their communities.

Peer pressure that is against female students taking science related programs was noted also by some (30\%) principals to have been taking among students who happened to have come from the same secondary schools or from among friends. The other (70\%) principals did not however see this as a problem as they noted that students do meet in the college after they had been admitted for various programmes as such very few were turning up to alter their programmes to which they must give convincing reasons to the admission committee.

A few (33\%) heads of departments noted peer pressure as a challenge to female taking science related programmes. Most (67\%) shared the feelings of the principals that students were joining colleges after admissions were not easily altering their programmes. Some (41\%) students however noted that their friends do influence them to change their programmes or encourage them to take similar units with them. These however were minimal cases that were not creating any impact on the student population.

Lack of role models of ladies who have excelled in science related programs. This was not of great impact as was only noted by only (20\%) principals. Equally only (31\%) heads of departments felt it was an issue but depends on the background to where specific students were coming from. To students, less than half (34\%) were able to see role model as factor since female students who had excelled in science were many all over the country.

\section{Policy Initiatives to Promote Female Access to Science Related Programs}

The fourth objective was to establish policy initiatives to promote female access to science related programs. The research question responded to was: What are policy initiatives that can promote female access to science related programs? The respondents were asked to rate the contributions of the stakeholders to quality leadership, their responses were as shown in Table 4.8.

Table 4.8: Policy Initiatives to promote female access as reported by Principals $(n=8)$, Heads of departments $(n=40)$ and Students $(n=900)$

\begin{tabular}{|c|c|c|c|}
\hline Policy initiative to promote female Access & $\begin{array}{c}\text { Principals } \\
\text { Mean Rating }\end{array}$ & $\begin{array}{c}\text { HoDs } \\
\text { Mean Rating }\end{array}$ & $\begin{array}{c}\text { Students } \\
\text { Mean Rating }\end{array}$ \\
\hline Give advice towards science related programs & 3.2 & 4.9 & 4.9 \\
\hline Female students who excel do get sponsorship & 3.2 & 4.7 & 4.8 \\
\hline Equip the institutions with relevant and modern equipments for science related program & 2.7 & 4.6 & 4.6 \\
\hline Talk positively & 2.4 & 4.4 & 4.3 \\
\hline Providing enough books for doing research & 2.1 & 4.4 & 4.2 \\
\hline Lowering grade requirements for science related programs & 2.0 & 4.1 & 4.0 \\
\hline Girls to be given priority during selection of students for science related programs & 1.7 & 3.7 & 3.9 \\
\hline Adjust the college environment to suit female students & 1.5 & 3.5 & 3.7 \\
\hline Giving bursary to female students who are admitted on science related courses & 1.2 & 3.4 & 3.6 \\
\hline
\end{tabular}

Give advice towards science related programs, Female students who excel do get sponsorship, Equip the institutions with relevant and modern equipments for science related program and talking positively was highly rated by all categories of respondents who participated in the study. 
On the other hand, the initiatives like, Providing enough books for doing research, lowering grade requirements for science related programs, girls to be given priority during selection of students for science related programs, adjust the college environment to suit female students and giving bursary to female students who are admitted on science related courses were averagely rated by all categories of respondents who filled the questionnaires

Give advice towards science related programs were established during interviews to be the most Policy initiative used by the technical institutions to promote female access to Science Related Programs. All (100\%) the principals who participated in this study indicated that their institutions do have orientation programmes that do encourage female students to enroll in science related programmes. According to the heads of departments, departments do have strong guidance units that do offer career guidance to those students who would want to enroll in science related programmes. They further noted that during orientation they do encourage the students and bring role models of female who had passed through the colleges so as to encourage female students on enrolling into science related programmes.

Students on their part supported the sentiments of their teachers that they were being well advised during orientations and were being allowed to alter the programmes they were initially admitted for. Students further maintained that teachers were very friendly to them and were offering good advice to the learners on the advantages of enrolling in science related subjects. They also noted that career guidance was really helping them to change their attitude towards science related programmes.

Female students who excel do get sponsorship was also explained by all (100\%) principals who participated on the study. They maintained that as a policy initiative their institutions were taking affirmative action to encourage female enrolment in science related programmes. Most (83\%) principals further maintained that many female students have learnt free from their institutions due to good performance. Some (17\%) principals maintained that their institutions had lined most students who excel with various companies, NGOs and other employers as a way of motivating especially female students to improve in performance.

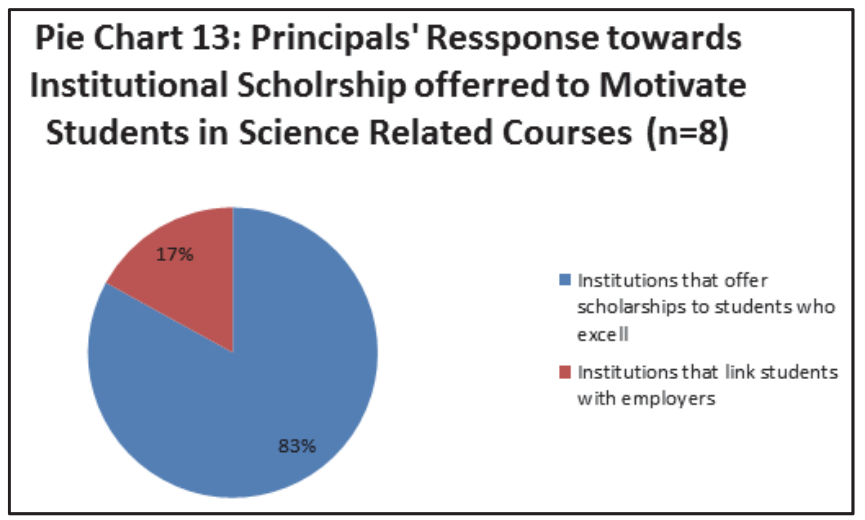

All (100\%) heads of departments concurred with their principals that they were encouraging high performance from the students by sponsoring the high achievers. Most (75\%) heads of departments explained that they were even linking the students who were excelling with their lined colleges abroad which finally make them to proceed for further studies abroad. Some (25\%) heads of departments added that the students were at times being absorbed by their institutions once they were through with their programmes and whenever opportunity arise for teaching or other jobs within their institutions.

Equip the institutions with relevant and modern equipments for science related program. This all (100\%) principals had noted through the introduction of e-libraries. The principals also noted the use of interlink with other institutions abroad as well as the improving on the institutions' physical facilities. All these they noted were to improve learning at the tertiary institutions. On the other hand, most (96\%) heads of departments maintained that their institutions were improving quality of programmes offered by purchasing new laboratory equipments, building new class rooms and also dormitories among other facilities being purchased. All these were meant to improve the quality of programmes and also to accommodate the large numbers of students who are registering a fresh for various programmes.

Most (91\%) students however did not agree with their teachers noting the institutions were doing very minimal especially the purchase of equipments was never done and if bought then it would be one or two. The students further narrated how they had obsolete machinery, out dated books for reference, very old computers among other poor equipments. Students believed that, these were the reasons as to why most female students were not enrolling for 
science related programmes.

Talk positively was used by tertiary colleges to help retain and attract new customers as was noted by most (95\%) principals. They further argued that students are customers who must be talked to well in order to make them accept the institution and the programmes that are offered in it. Some (73\%) principals added that most female students would want to be treated gently and that is why their institutions have adopted such option especially in science related programmes so as to win them.

Most (83\%) heads of departments concurred with the principals that their departments were using positive talking to the learners towards the programmes they were offering. They noted that each lecturer was using this approach to entice the learners especially female students who would see that the programmes were much demanding and were at the verge of giving up to other programmes perceived to be lighter. Such kind of talks has helped to retain most female and weaker male students in science related programmes.

Most (94\%) students also supported their lecturers that positive talking was used by institutions to help retain a number of students in their program which they dropped out of after completing their first semesters. Some (64\%) students further revealed that students initially apply for programmes when they don't know what the programmes entailed, but when they come in reality with such programmes demand, they do feel frustrated and would want to abandon the programmes. They then appreciate the way students were being encouraged that has kept many of them in the programmes.

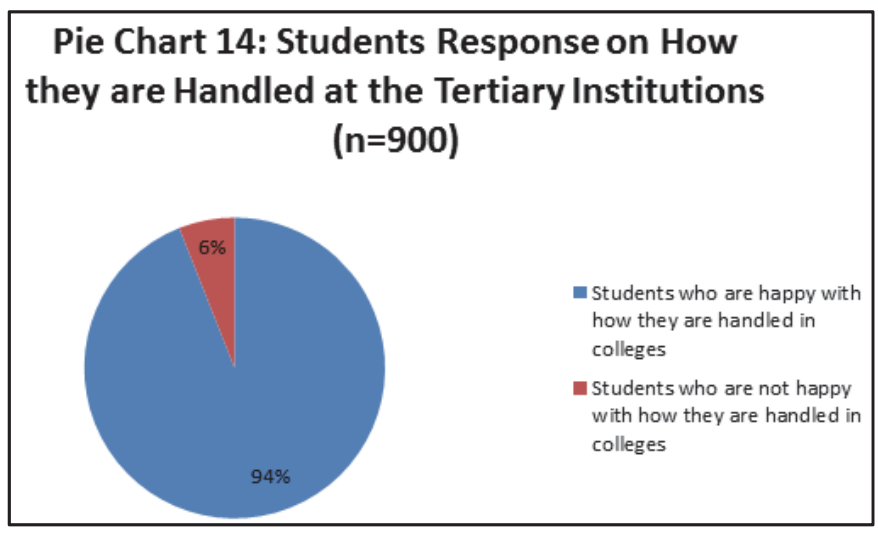

Providing enough books for doing research was also used as a policy initiative to promote female access as revealed by most (85\%) principals. They further explained that most of the colleges have adopted e-library services to their students. This they noted was not leading to book loses or books getting torn when being arranged or when in use. The principals however noted that they were also having other hard books which were very relevant and were being used by the learners.

Most (89\%) heads of departments echoed the sentiments of the principals that they do have a lot of good books in the libraries in form of e-books. Some (78\%) further maintained that it was their roles to scout for new books in the market to enable the departments acquire current but relevant materials for references. The heads of departments however descried the students' weakness of being hasty and lacing patience so as to enable them make good use of the e-library. On their part, most (75\%) students maintained that their colleges were lacking books for reference as the few which are there were not enough for the bigger population in the colleges. They however appreciated the e-library services offered by the colleges but noted that the computers were few and only a few students could access the e-library at one given time.

Lowering grade requirements for science related programs for female students was an affirmative action which was adopted by the Ministry of Higher Education to uplift female and other students from disadvantaged regions. All (100\%) principals noted they were offering such favours to the level accepted by the government. Some (76\%) principals argue that they were using such measures to bring gender parity in science related programs. Most (83\%) heads of departments concurred with principals that they were taking affirmative action of lowering grades for female students and suggested that they should be let to be at par with their male counterparts in science related programmes. Most (91\%) students also appreciated the action and noted that it was a good way of attracting female students. Some (42\%) students however expressed fear that the approach was becoming disadvantageous to female students when they come to examinations where affirmative action was not being taken. This they noted was one of the reason why most female 
students would want to change their programs after sitting the first semester examinations.

Girls to be given priority during selection of students for science related programs, this was being done on specific programs where female applicants are fewer than their male counterparts as was maintained by some (68\%) principals. They noted that specific science related programs were always having very few female applicants and colleges in such cases were giving priority to female applicants. This position was also echoed by most (65\%) heads of departments. Students also confirmed that female students were highly valued than male counterparts in certain programs. Although they appreciated the move but the students were having reservations that this move was likely to be abused by lecturers who might want favours from the few female students admitted for such programs.

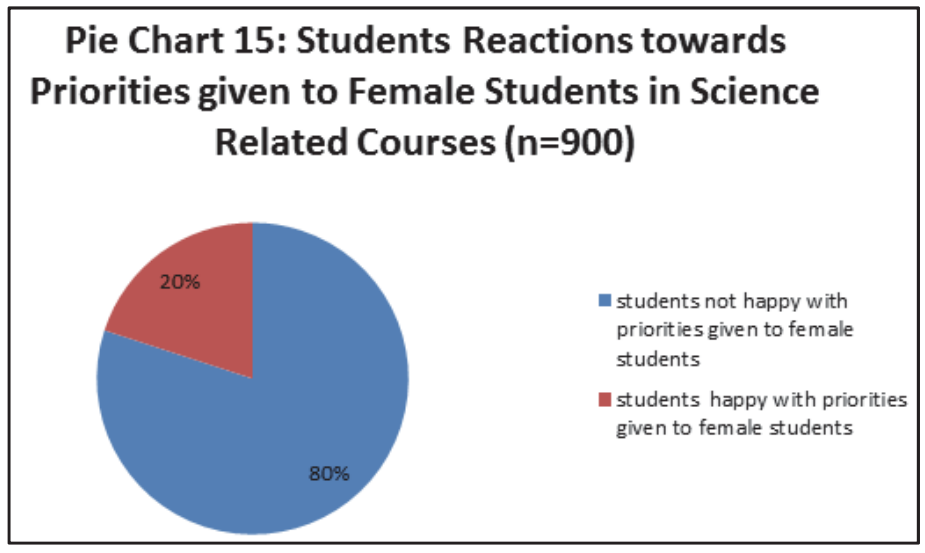

Adjust the college environment to suit female students was a process that was ongoing as noted by some (43\%) principals. The principals further noted that they were trying to improve on the esthetic values of the institutions so as to make more female like their environment. Some (34\%) heads of departments were also in agreement with their principals. This they noted was also a way of ensuring good hygienic conditions of the colleges. Some students however felt that little was being done to make the colleges female friendly

\section{Summary, Conclusions and Recommendations}

\subsection{Summary}

Summary of the study is presented under themes derived from research objectives.

The major findings of the study included

There is still a strong belief among the students that Science courses are meant for males and female students.

Science achievement at KCSE level gives a firm foundation for the programs at tertiary level

Most institutions of technologies have poor science facilities like laboratories and equipments, text books

Lecturers attitude towards female students enrolled in science related programs was hindering enrolment

Belief that science is difficult for girls but easy for boys is still affecting female enrolment in science related programs.

Poor economic background deter most female students from enrolling into science related programs.

The institutes managements were giving female students advice towards science related programs to attract them to such programs.

Female students who excel do get sponsorship from the institutes as away of motivating female students to aim higher

\subsection{Conclusions}

The administration in the technical training institutes are reluctant on their role to provide science facilities like laboratories and equipments, text books

No proper orientation is done to the new students at the technical training institutes as most female students are receiving discouragement from peer pressure to drop science related programs. 
Belief that science is difficult for girls but easy for boys is still affecting female enrolment in science related programs.

Poor economic background deters most female students from enrolling into science related programs.

The institutes' managements were giving female students minimal guidance towards science related programs to attract them to join such programs.

The sponsorships offered by technical training institutes were of low magnitude and does not attract most students to perform well.

\subsection{Recommendations}

With regard to the factors hindering enrolment of female students in science related programs, this study recommended that

The administration of the institutes should stop the belief among the students that Science courses are meant for both male and female students.

The government should emphasis to the students at secondary level that science achievement at KCSE level gives a firm foundation for the programs at tertiary level

Technical training institutes should improve their science facilities like laboratories and equipments, text books

Lecturers should be made to have positive attitudes towards all students so as not to inhibit students aspirations in science related programs.

Serious career guidance should be offered by technical training institutes to demystify the belief that science is difficult for girls but easy for boys.

The government should subsidize the cost of studying science related programs at technical training institutes to enable more student enroll in the programmes.

More funding should be allocated to technical training institutes so as to cater for the students who are unable to meet the cost of science related programs.

More scholarships should be availed to female students who excel in science related programs.

\section{References}

Adeyemi, K. \& Akpotu, N. (2004). Gender Analysis of students enrolment in Nigerian universities. Humanities and social sciences and Law. 48 (3): 361-378.

Amuka, L. (2003). Gender enrolment in Tertiary Institutions: Case of Mombasa Polytechnic. Unpublished M. Ed. Thesis, Maseno University.

Baker, D. (2007). Letting girls speak out about science. Journal of research in teaching, 32 (1), Pg 3-27.

Bunyi, G. (2004). Gender disparities and higher education in Kenya: nature, extent and way forward. The African symposium, 4 (1), 4361. Retrieved from http://www.nesu.edu/aern/TAS4.1.pdf

Bush, T. (2004). Theories of Education Management. London Sage.

Catsambis, S. (1995). Gender, Race, ethnicity and science education. Journal of Research in Sciences Teaching 32 (3) pp 243-251.

Chege, F. \& Sifuna, D. (2006). Girls and Women Education in Kenya: Gender Perspectives and Trends. UNESCO.

Egbochuku, E. (2008). Socio economic status and vocational interest as correlates of re-entry girls into school in Edo states. Benin Journal of Gender studies 1 (1): 31-36.

Gerson, K. (1995). Hard choices, How women decide about work, career and motherhood. Berkeley, university of California press.

Hardy, M. \& Bryman, A. (2009). The handbook of data analysis. London: Sage publications.

ILO (2000). ABC of women workers right and gender equality. ILO Geneva pp 2-48.

Imogie, A. (2007). Stereotypes about sex and leadership: Hurdle to overcome Journal of Gender studies 1 (1): 1-4.

Imogie, A. Eraikhuemen, L. (2008). Inquiry into sex differentiation in admission and academic performance at university of Benin, Nigeria. Journal of gender studies 1 (1): 14-20.

Jacobs, J. (2005). Twenty-five years of research on gender and ethnic differences in maths and science career choices: What have we learned? New direction for child and adolescent development, 110: 85-94.

Kahle, J. \& Meece, J. (2004). Research on gender issue in the science classroom. In Handbook of Research on Science Teaching and Learning, Gabel (Ed). New York: Macmillan Publishing company.

Kerlinger, F. (2003). Foundation of Behavioural Research, $2^{\text {nd }}$ Edition. New York: Holt Rinehart and Winston Incorp.

Leedy, P. (1993). Practical Research: Planning and Design. New York: Macmillan publishing Company

Mugenda, O. \& Mugenda, A. (1999). Research Methods: Quantitative and qualitative pproaches. Nairobi: Acts Press Kenya.

Okebukola, P. (2002). The state of universities in Nigeria. Ibadan: Heinemann.

Okeke, E. (2004). Gender sensitivity in classroom interaction. A paper presented at an Education Tax Fund/National Commission of 
Colleges of Education workshop held at Federal college of Education (Technical) Asaba.

Okeke, M. (2000). Gender gap and access to secondary schools: women and girls participation in science and technology and mathematics; educators and facilitators. Conference of Nigeria's Academic of education, Inugu. Pg 19-21.

Orodho, J. \& Njeru, E. (2003). Access and participation in secondary school education in Kenya: Emerging issues and policy implication. IPAR discussion paper No. 037/200. Nairobi: Institute of Policy Analysis and Research (IPAR).

Owiye, D. (2005). Trends in and factors affecting wastage in primary education in Siaya District. Unpublished M. Ed. Thesis, Maseno University.

Psacharopoulos, G. \& Maureen, W. (1985). Education for Development Analysis of Investment Choice. London: World Bank.

Republic of Kenya (2002). National Development Plan 2002 - 2008. Nairobi: Government printers.

Republic of Kenya (2005). Ministry of Gender and Children Affairs. Nairobi: Government printers.

Republic of Kenya (2007). Gender Policy, Government of Kenya (Vision 2030). Nairobi: Government printers.

Republic of Kenya (2011). Ministry of Education Statistical Booklet. Nairobi: Government printers.

Salman, M. \& Olawoye, J. (2008). Education reforms in Nigeria Implication for Education of the Girl child. Lagos, Nigeria.

Stromquist, N. (2001). Gender disparity in education access and attainment. Los Angeles, C.

Tyson, S. \& York, A. (1996). Human Resource Management, 3' $3^{\text {rd }}$ edition. Great Britain.

UNESCO (1998). World Education Report. France, Paris. UNESCO

UNESCO (2003). Gender and Education for All. France, Paris. UNESCO

UNESCO (2008). Regional Overview: Sub-Saharan. UNESCO.

UNESCO (2011). What is Gender Equality? Gender Equality across the Globe. Retrieved from http://genderpolicyforum.wordpress. com/why-this-policy-forum-2/

Vianello, M., Siemenska, R., Damian, N. \& Luprine, E. (2000). Gender inequality: Comparative study of discrimination and participation. London: AGE Publication Ltd.

Wasanga, P. M. (2010). Science Education in Kenya, submitted to planning education at Secondary level. Johannesburg: IIEP and CEPD.

Woodward, A. E. (2002). Going for gender balance: A guide for balancing decision-making. Retrieved from http://eacea.ec.europa. eu/education/eurydice/documents/thematic_reports/120EN.pdf

Yahaya, L. A. (2004). Disparity in enrolment of male and female undergraduates in science and technology based faculties, implications for counselling. Nigerian Journal for counseling and applied psychology, 2(1); pg 186-201. 
